\title{
Colonial Intervention to a New Equation of Politics in India's Northeast
}

\author{
Mayuri Bora $^{+}$
}

\section{Abstract}

Colonialism has its impact on Indian politics and society even after the colonialism. Pre-colonial Assam was able to maintain its independent status till 1826. After incorporating into the company's holdings, colonialists gradually extended their controls to the hill areas surrounding the Assam and Bengal plains. Subsequent to annexing the hills, the areas were designated as "tribal" areas and continued to be ruled as a distinct administrative regime. However, the strategy of divide and rule system had fundamentally changed the practices of both hills and the plains. For segregating the hills from the plains, a line was drawn, known as Inner line of 1873. The gradual separation and sharpening of identity had led to the formation of 'Bordoloi Sub-committee to render autonomy to the hill people. However, the recommendation made by the 'Bordoloi Sub-committee' were not able to fulfil the aspirations of the hill tribes, and they started demanding for more autonomy in the form of statehood, backed by insurgent activities, which paved the way for the reorganisation of Assam. And in the present juncture, the Plain tribes of Assam have been demanding for rereorganisation of Assam. Hence, this study specifies the colonial subjectivity and subjugation and its consequences to new equations of contemporary politics.

Keywords: Colonial intervention; Politics; Identity; Autonomy; Reorganisation; Assam

\footnotetext{
${ }^{+}$PhD Scholar, Department of Social Sciences (Political Science), OKDISCD, Dibrugarh University, Email: mayuribora24@gmail.com

(C) 2020 Bora. This is an Open Access article distributed under the terms of the Creative Commons Attribution License (http://creativecommons.org/licenses/by/2.0), which permits unrestricted use, distribution, and reproduction in any medium, provided the original work is properly cited.
} 


\section{Introduction}

India's Northeast consists of the states of Assam, Nagaland, Mizoram, Arunachal Pradesh, Manipur, Tripura, popularly known as the 'Seven Sisters' states and Sikkim is the last and eighth one to become a member of the Northeast after the formation of North Eastern Council. Foreign countries encircle the region, which includes Bangladesh, Bhutan, China, Myanmar, and Tibet with 99.5 per cent of the international border. The only land link to the rest of India is the Siliguri Corridor of the state of West Bengal. The idea of 'north-eastern frontier' was first evolved in the colonial period by colonising the Brahmaputra valley and surrounding hill areas of the Indo-Burma frontier. In post-Independence India the terminology "NE" got a boost when Prime Minister Jawaharlal Nehru created the North-East Frontier Agency (NEFA) in 1951. Instead, subsequent developments stand to legitimise the "NE" as an entity (Ngaihte, 2013). The term 'tribe' was as well first used by the colonialist to refer to the indigenous people of the then composite Assam. After colonialism the Indian Governments also followed the same earlier British policies of "primitive tribes" or "backward tribes" (Karlsson, 2014) to refer the Indigenous people of the Northeast.

To understand contemporary India's Northeast, it is essential to understand the grounds for the feeling of being colonially exploited even after independence. The same process of divide and rule has been implementing through providing different territory-specific Autonomous Councils for the different communities where other communities feel that their autonomy has eroded because the particular council specify the particular community. The mobilisation of social forces, in asserting their identity within their respective communities is responsible for leading to the inter-community conflicts simply for being different ethnic communities following their own sub-culture. However, the fact remains, that inter-community conflict frequently called ethnic community conflicts are an important part of the societies and polities of Northeast India (Baruah, 2003). Hence, the same episode has been repeated in the question of ethnic identity and autonomy in India's Northeast.

Before going to discuss colonial impingement to India's Northeast, it is essential to define what colonialism denotes. "Colony" comes via French from the Latin colonia and colonus, farmer, from colere, to cultivate, dwell. Colony came to refer primarily to invasive settlements, not to a neutral "dwelling" (Bob and Vijoy, 2005). Ranajit Guha and Gayatri Chakravorty Spivak argued that introduction of colonialism to India is a change from semi-feudalism to capitalist subjection for the inauguration of politicisation for the colonised. Later it contributes to form 'bourgeois nationalist' from the parts of the indigenous elite to form Indian nationalism (Guha and Spivak, 1988). Guha writes both colonialist elitism and bourgeois-nationalist are the product of British rule in India and have been assimilated to neo-colonialist and nationalist forms of discourse (Guha and Spivak, 1988) to create hegemony of colonial subjectivity. MackCanty (2004) argues that in the phrase postcolonialism, the term 'post' does not necessarily mean the process of decolonisation but instead indicates the continued existence of a colonial legacy to form a new driving force called 'recolonisation' contributed by the global capitalist economy (Bhattacharyya, 2009). In fact, contemporary American, African, and Asian national boundaries are part of the colonial inheritance depicted by the imperial powers according to their administrative and political convenience without taking into account the cultural, ethnic, linguistic, or historical differences among the diverse populations contributed to the ethnic and national violence. As, Jose Carlos Mariategui (1894-1930) noted in the 1920s, colonial practices, institutions, and ideologies enters as an 'internal colonialism' to present politically independent nations in which cultural, racial, ethnic, religious, linguistic, or caste differences form the basis of the institutionalised economic exploitation of one group by another (Castro, 2014). Ella Shohat's suggest that post colonialism concerns itself with 
"continuities and discontinuities on the new modes and forms of the old colonialist practices" and not on a "beyond" (Bob and Vijoy, 2005: $375)$ hence the consequences.

The central objective of the study is to understand how the colonial pattern of administration had impacted on India's Northeast and its consequences to contemporary discourse.

The study is descriptive and analytical in nature. It is based on secondary information from books, journal articles, various governmental reports and other relevant online sources. The study begins with a discussion of constructing colonial space as a way of deconstruction of the natural space. Then it discusses the dichotomy between the hills and the plains as created by colonials. In the final section, the study discusses the dichotomous autonomy of the scheduled areas.

\section{Constructing Colonial Space after Deconstructing the Natural Space}

In the Northeast, the intentional constitutional consideration for integration through accommodative autonomy within the interface of geo-politics and ethno-politics led to the outgrowth of autonomous space under the Sixth Scheduled of the Constitution. The colonial and post-colonial subjectivity has emerged as a fundamental principle of gradual separation for reorganising society. The then 'Assam Proper' includes the five districts of Kamrup, Darrang, Nowgong, Sibsagar and Lakhimpur, together comprising an area of about 20,000 sq. miles came under British occupation in 1825 (Guha, 2006). The signing of the Yandaboo Treaty in 1826 led Assam officially to the hands of the British, made Manipur a vassal state. In the earlier period, the primitive base of North East India was basically clan or kinship space, widely varied from one clan to another and each occupied certain territorial space without any identified territorial category confined to their

\footnotetext{
${ }^{1}$ Posa system was a pre-colonial mechanism for controlling the communities especially the Akas, the Daflas, the Miris of the northern frontier. They were permitted to collect a share of the agricultural production from the farmers in the plain (Sharmah, 2016).
}

family, clans, and villages (Sarmah, 2016). In the Ahom period, the Ahom-tribal relationship was not based on any rigid criteria and not aims to extend its sovereignty over the hill areas, but the establishment of friendly relationship with them was on the basis of mutual benefits and understandings (Baruah, 2015: 382). The Ahom kings allowed the Nagas and other hill chiefs to collect posa tax from the foothills in order to maintain friendly relations with tribal chiefs (Das, 2018: 53). Adopting the same Posa system ${ }^{1}$ colonial administration made arrangements for collecting Posa in cash instead, of a share of production of the villagers (Sarmah, 2016). The procedure adopted for the administration of the plains (the Brahmaputra valley) was not adopted for the hills. In the hills, rural policy and maintenance of law and order were left to the local chiefs but, punitive expeditions were sent against those "tribes" who violated the agreement, committed raids and disturbed the peace of the borders (Lahiri, 1975).

The surveys followed the annexation of Assam, resettlements and restructuring of administration for effective land management and revenue collection to make the geographical space as the basis of the administrative units. In fact, the land was becoming the most critical source of revenue in the plain areas and in the hill areas house tax was the substitute for the land revenue (Bhattacharjee, 2018). This had led to the beginning of a new interventionist policy for all kinds of structural changes, and gradually led to the first phase of resistance to the region by the old Aristocracy, the Singphoes (a tribe of Burma Border 1830-31), peasants of Jaintia Hills but later had to surrender before the superior arms (Guha, 2006). It was after the acquisition of the Diwani of Bengal ${ }^{2}$ in 1765 that the East India Company came into direct contact with the medieval kingdoms of Manipur, Jaintia and Assam, as well as the tribal communities of the adjoining hills (Guha, 2006). As Sarmah writes,

\footnotetext{
2 'Diwani' was a provincial revenue administration system under the Mughals and an early mechanism of the establishment of the company rule in Bengal. After the Battle of Buxar, with the Treaty of Allahabad of 1765, the Diwani of Bengal was granted to East India Company (Singh, 2017).
} 
the direct colonial administration was uniformly introduced and stabilised over the entire erstwhile Ahom kingdom after explorations of various economic potentials especially of tea, during the first decade of colonial occupation (Sarmah, 2016: 18). The colonialist needed Assam mainly for its tea, and later petroleum (Fernandes, 1999). The policy of allowing the tribe to enjoy their autonomy was initially followed by the Britishers as well. However, they soon adopted a radically different policy towards all tribes (Baruah, 2015: 385). After annexing, the kingdom of Jaintia, Cachar and Assam along with their dependencies, and all the small, independent tribal states of the Khasi hills, North Cacher Hills were all organised into a separate administrative unit in 1854. Further annexation of the remaining hills was subsequently completed step by step in the face of stiff tribal resistance. Colonial administration, on many occasions, considered changing Assam's boundaries (Baruah, 1999). Consequently, the British annexed the hills from all the sides. Thus, the hill areas of northeast India entered the age of politics. Nevertheless, the British province that came to be known as Assam had more or less taken shape by 1873 and gradually transformed local traditional institutions to suit the colonial pattern of exploitation. Throughout the entire colonial period, the British treated Assam as a land frontier of Bengal (Baruah, 1999).

To make the ground for colonial economy, the Raj had started the process of transformation of rules and regulation for their convenience. The Charter of 1833 granted the final ascendancy of British industrial interest over mercantile interest, the Wasteland Rules of 6 March 1833 were framed to make the waste lands available for plantation economy, and wage slaves on the plantation were started. The rules were apparently framed in such a manner as to exclude indigenous aspirants from all concessional grants in practice. Alongside, missionary and administrative activities led to the founding of English schools and printing press, an infrastructure based on where a colonial hybrid bourgeois culture could now emerge (Guha, 2006: 16). The British policy of minimal spending and intervention in the administration of the hills left the missionaries with "the burden" of bringing the tribal's into the light of the modern world. Christianity in many respects prepares the people to face the impending modernity by helping to form a new identity (Pachuau, 1997). The beginning of modern political consciousness, as well as the new elite formation in the Brahmaputra Valley can be traced from 1853. The germination of a new politics had started with the formation of various Sabhas and Societies. In 1857 the Assam Desh Hitashini Sabha, 1857-59 the Jnan Pradayini Sabha, 1872 the Assamese Literary Society was formed in Calcutta at the initiative of its Assamese residents. Bengal renaissance also had its impact on Assam, reflected the drawing of a modern political consciousness in the Brahmaputra Valley (Guha, 2006: 19). Accordingly, in 1874, Assam proper together with Cachar, Goalpara, Garo Hills and the other hill districts was formed into Chief Commissioners Province on 6 February 1874 was given a broader significance to denote the newly emerged composite province (Guha, 2006: 23).

The tremendous growth of the tea industry led to the time of colonial glorification of exploitation in its height with the alignment of railway in favour of the tea industry. However, the land-abundant economy of the Brahmaputra Valley failed to grow enough food grains to feed its increasing population, many deaths due to starvation had been reported and population were decreased in sharp contrast. Aftermath, the influx of immigration neutralises the decline of the indigenous population. The land revenue rates under the new settlement of 1892, led to the most tragic incident of Patharughat in Mangaldoi sub division. This lead to further growth of modern political consciousness. A new phase of constitutional participation in the legislative process was also growing in the minds of the Assamese middle class. In 1905, Assam's status as a new separate province was going to be called North Eastern Province and Assam's Legislative Council 1912-20 had become a glorified debating society (Guha, 2006). With this, the pan-Indian connotation had come to the path. 


\section{Colonial Creation of Dichotomy between Hills and Plains}

Colonial creation of dichotomy between hills (primitive) and valleys (civilised), and the creation of the cultural-political and administrative binary started with the inner line Regulation of 1873 . It continued until the government of India Act of 1935. In April of 1874, the Scheduled District Act, was enacted, and the entire Chief Commissioner of Assam was declared to be Scheduled District (Hansaria, 2005). The term "Scheduled District" was understood to mean "those remote or backward tracts or province of British India which had never been brought within or had time to time been removed from the operation of the general acts and regulations". The Government of India Act, 1935 gave up the terminology of the backward Tracts and instead described the areas either as excluded areas or partially excluded areas (Hansaria, 2005). These were the territories, which were specified as tribal areas in the Sixth Schedule to the Constitution as originally enacted, had been recommended by the 'Bardoloi Sub-committee'. The 'Bordoloi Sub Committee' studied the problems of the tribal people of the region. The Committee realised that to protect and preserve the way of life of the tribes along with others, those areas needed protection and safeguard from the people of the valley, especially from the money lenders. The idea of the Inner Line emerged to maintain its territorial boundaries, as the limits of the district were at first thrown very far forward to exercise jurisdiction all the way too far to the hills. Therefore, it became necessary to draw a line up to where the colonial administration intended to work and beyond the line, the tracts were left unadministered. The outer line was purposely left indefinite so that the inner line could be advanced when necessary (Das, 2018). By 1942, North Cachar and all the hills except for the Khasi, Garo and Mikir were encircled. The concept of political control on an ever-expanding frontier through the policy of exclusion and seclusion as museum specimens remained excluded from all constitutional reforms threatened British political relations with the hill tribes. British officials only allowed Christian missionaries to operate in those areas. Even Assam's elected chief ministers were not allowed to operate in those areas. Indeed, the missionaries were immensely successful in colonial Assam (Barua, 1999). There was practically no political development in the hills except for the Khasi-Jayantia hill district, until the end of World War II. Through Christianity and literacy, missionaries have been instrumental in reproducing the construction of tribal identity, particularly among the hill tribes which have helped embedded colonial classifications into the social, political and economic relationships between the church, state and civil society and transmit the gospel of tribal groups. Pels and Salemink (1999) argue that the necessity to communicate in and teach a language made missionary education one of the major factors in the production and reification of these ethnicities (Mc DuieRa, 2009).

Until the British advent, the notion of political authority was unknown to the hills. In Nagaland, some marginal activity of a political nature may be traced back to 1918 when the Naga Club was formed to discuss their social and administrative problems. During the time of the World War the men of the hills came in contacts with the soldiers of many provinces and many nations. As a consequence, these hill men got exposure to the outside world and gradually learned politicisation. The partition of the country largely disrupted the hill economy, since some parts of the Garo, Mizo, Khasi and Jaintia hills had long been economically more integrated with Eastern Bengal than with the plains of Assam. They had to undergo untold hardship because of the disruption of their normal trade channels. This further strengthened their urge for local autonomy (Guha 2006; 264). The year 1946 saw the formation of several district-level tribal political organisations in the hills, initiated a hill union with members drawn from the different hills. The economic transformation of Assam during the British rule and the attendant demographic changes because of immigration and the beginnings of Assamese subnationalism, with the newly emerging elite, had further brought the question of the ethnic 
equation of new politics of breakup of Assam. The administrative units, boundaries were demarcated arbitrarily when new areas were annexed in the aftermath of an armed expedition by the colonisers during the colonial expansion without factoring in ethnoscape, which resulted in the segmentation of ethnic community. Thus most of the ethnic mobilizations in Northeast India in the postcolonial period are for reunification of the territory inhabited by the ethnic communities, which were segmented by the colonisers to suit the interest of the imperial design (Piang, 2013).

\section{The Dichotomy to Autonomy as Scheduled}

\section{Areas}

The political struggles of autonomy have been contributing to a wide variety of constitutional forms in India. The Sixth Schedule of the Indian Constitution made special provisions for the administration of the 'Tribal Areas of Assam' comprise those districts, which have elected councils with powers to regulate the customary law; to administer justice in limited cases; and to determine the occupation or use of land and the regulation of shifting cultivation. At the time of the inauguration of the Constitution in 1950, some tribal areas were required to have elected councils immediately. However, other tribal areas that were largely un-administered during colonial times or where state institutions were the least present Sixth Schedule became a good way to ensure both the penetration of the state and the creation of local stakeholders in the panIndian dispensation (Baruah, 2003). The British Cabinet Mission visited India prior to independence and encouraged to form an Advisory Committee for effective and appropriate management of the Tribal Areas. Thus the recommendations made by the Advisory Committee was appreciated and taken forward to form the Sub Committee. This Sub Committee, as already mentioned above, is known as the Bordoloi Sub Committee which noted the existence of the traditional tribal selfgoverning institutions which functioned democratically and settled their disputes following their own customs and traditions. To provide a proper constitutional set up for the tribal areas of North East was debated in the Constituent Assembly, which drew distinct shades of opinion, regarding how the tribal communities "ought" to be incorporated into a unified Indian state: assimilation of individual tribe's people into a common national Indian community, and integration of tribal communities into a multicultural Indian nation. Both notions have found their way into India's Constitution (Constitution Assembly Debates, 1949). During the debate, the draft provision underwent many amendments. In the end, political integration was accepted through Sixth Schedule provisions and added Article 244 (2) of the Constitution, provisions of the Sixth Schedule for the administration of the tribal areas of the present states of Assam, Meghalaya, Tripura and Mizoram in accomplishment with legislative, judicial, executive and financial powers.

The instructive form of accommodative autonomy has been experienced in post-colonial India because of its diversity, the extent of colonial experimentations, multiple forms of autonomy aspirations, and the relentless demands for self-determination in various forms. The Constitution provides special status for certain states such as Jammu and Kashmir, Nagaland, Sikkim, Assam, Manipur, Arunachal Pradesh in Articles 370 to $371 \mathrm{H}$. Apart from creating new state and autonomy for some states, in particular, a range of accords and unilateral measures were adopted for Darjeeling, Bodoland, Leh, North Cachar Hills, Karbi Anglong district, Khasi Hills district, Jaintia Hills district, Tripura Tribal Areas district, Chakma, Mara, and Lai districts in Mizoram, created autonomous areas and district councils under the Fifth and Sixth Schedule of the Indian Constitution (Samaddar, 2008). Furthermore, after independence, Assam has been economically, politically and culturally colonised by the Indian government. According to Subir Bhaumik, since post-colonial India has been ever willing to create new states or autonomous units to fulfil the aspirations of the battling ethnicities, the quest for an ethnic homeland and insurgent radicalism as a means to achieve, so, insurgencies never peter out in Northeast, even 
though insurgents do. The same drama has been repeated throughout the last six decades, state after state (Bhaumik, 2009: xvi). The policy of protecting customary law and the preferential policies for reorganisation as such only within the colonial ethno-territorial frame has in effect meant the official acceptance of the logic of de facto ethnic homeland (Baruah, 2008). Besides, Hiren Gohain writes the capitalist development within colonial constraints during the colonial period, and the intervention of the welfare state after independence gave the impetus to the ethnic movements (Gohain, 1997) in India's Northeast.

In the land of the seven sisters, (at present eight, including Sikkim) the Sixth Schedule is applicable for the tribal people in four states, viz. Assam, Meghalaya, Mizoram and Tripura, while Arunachal Pradesh, Nagaland and Manipur have remained out of this arena. Being the princely states- Manipur and Tripura were outside from the reference of the Bardoloi Sub-Committee. Only on $15^{\text {th }}$ October 1949 , both these princely states were integrated with the Indian Union. However, the Sixth Schedule autonomy accommodation process has not been able to fulfil the aspirations of the hill tribes, and gradually they demanded more autonomy. The creation of Nagaland in 1963, Nehru's policy of maximum autonomy, shelving the Pataskar Committee Report ${ }^{3}$, the controversy over Ashok Mehta Committee Recommendations ${ }^{4}$, the rigid attitude of All Parties Hill Leaders Conference are some of the factors that are responsible for making the problem more critical. State-wide resentment was apparent in the year 1968; the slogan of "Assam for Assamese" and the destruction of the mass public and private property is a great challenge to the unity of Assam and the country as a whole. Assamese people were not convinced by the central government and All Parties Hill Leaders Conference's decision. The Lok Sabha passed the

\footnotetext{
3 Pataskar Committee was appointed by Lal Bahadur Shastri in March 1965. The Committee was headed by $\mathrm{H}$. V. Pataskar, a former Union Minister for Legal Affairs. The report of the Committee was based on the hill areas of Assam to confer full autonomy for preservation of the unity of the state of Assam (Mukerjee, 1969).
}

constitution (22 ${ }^{\text {nd }}$ amendment) bill on 15 April 1969 , to pave the way for the reorganisation of Assam with the creation of an autonomous hill state (Singh and Garg, 1969). Gradually a distinct entity as Northeast India has emerged as a significant administrative concept with the North Eastern Reorganisation Act, 1971. Assam became one of the seven Northeastern states with the emergence of six other states starting with Nagaland in 1963 then Manipur, Tripura, Meghalaya, Mizoram, Arunachal Pradesh. However, the process goes on in the name of ethnic identity and autonomy of the hill and plain tribes of Assam. They are now continuously demanding for separate statehood and reorganisation of Assam.

\section{Concerns for Autonomy in the present Context}

From the last two decades, the autonomy of the plains tribes of Assam has become a contested issue, particularly the Bodos of Assam. They were the first one to constitute the Plains Tribal Council of Assam (PTCA). The continuous engagement for the autonomy of the Bodos led to the signing of an accord in February 1993, between the Assam Government and the Bodo activists and formed an elected body called the Bodoland Autonomous Council (BAC) within the state of Assam under the Sixth Schedule of the Constitution of India. However, the lack of a clear-cut territorial boundary posed the biggest hurdle to the survival of the council. The then State Government was willing to include not more than 2,570 villages under the BAC jurisdiction as against 3,085 villages demanded by the Bodo leaders. As a result, elections to the council could not be held. The lackadaisical functioning of the BAC led to the feeling among the Bodos that only a Bodoland state could fulfil their aspirations. The revival of statehood agitation coincided with the emergence of a separate brand of militancy (Singh, 2008). However, again a Memorandum of Settlement

\footnotetext{
${ }^{4}$ The Janata Government in December 1977 appointed a committee on Panchayati Raj Institutions under the chairmanship of Ashok Mehta. The Committee gave some suggestions or scheme for the division of powers to revive and strengthen the declining Panchayati Raj system in the country (Mukerjee, 1969)
} 
(MOS) was signed in New Delhi among the representative of the Central Government, the Assam Government and the Bodo Liberation Tigers (BLT, an armed organisation) leading to the creation of the Bodoland Territorial Council (BTC) for the fulfilment of economic, educational and linguistic, socio-cultural aspirations of the Bodos along with the infrastructure development of BTC area. The area under BTC jurisdiction is officially called the Bodoland Territorial Area Districts (BTAD) consist of four contiguous area districts named Kokrajhar, Baksa, Udalguri and Chirang.

Further continuation of issues like land alienation of tribal people, socio-culturaleconomic backwardness of the Bodo people shows the inability of the BTC to fulfil the expectation of the Bodo people restates their earlier demand of separate state within India. Interestingly, the National Democratic Front of Bodoland (an armed separatist outfit, traces its origin from Bodo Security Force) had rejected the second Bodo accord and at the same time demand a sovereign state instead of separate statehood (Singh, 2008). Recently, on $27^{\text {th }}$ January 2020, the Centre and the Assam Government signed a Peace Accord with the Bodo Organisations (National Democratic Front of Bodoland and All Bodo Student Union) and the autonomy has been further extended, which is known as the Bodoland Territorial Region (BTR).

Besides, the issue of autonomy for the hill tribes of Assam can be traced from the Government of India Act of 1935. Under this act, North Cachar were classified as 'Excluded area' and Mikir (Karbi) hills as 'Partially Excluded area'. After the independence, the Constitution of India broadly accepted the spirit of the Government of India Act of 1935 by providing each hill district with an Autonomous District Council with a reasonably large autonomous power under the Sixth Schedule. The Reorganisation of Assam Act 1969 had given the option to these two districts either to join or not join the first Autonomous State of Meghalaya. However, they refused to join and enthusiastically decided to stay with Assam (Hussain, 1987). However, from 1986, both Karbi Anglong and North Cachar have been witnessing the autonomous state movement for separate statehood. More autonomy was granted to Karbi Anglong Autonomous Council through vesting the status of fully-fledged Autonomous Council in 1995 and later signing Memorandum of Settlement (MOS), has renamed the Council as Karbi Anglong Autonomous Territorial Council. In 2012, two factions of the Dima Halom Daogah of Dima Hasao signed a tripartite agreement with the Central Government and State Government to bring to an end to violent movements. According to the Memorandum of Settlement (MOS) the North Cachar Hills Autonomous Council would be recognised to Dima Hasao Autonomous Territorial Council granting more financial and administrative powers to the council. After the post BAC sequences in 1993, the other plains tribes of Assam has culminated a series of political unrest and agitations. As a result of such demand from the plains tribes, the Assam government has signed the Mising, the Tiwa (Lalung) and the Rabha Accords in 1995. In the second stage, Memorandum of Understandings (MoU) was signed between the Assam government and the leading organisations of the movements of the Sonowal Kachari, the Deori and the Thengal Kachari during 2005 (Functioning of Autonomous Councils in Sixth Schedule Areas of the North Eastern States, 2016). This pattern of administrative authorities is setting with an objective to provide them the maximum possible autonomy through satellite form of autonomous councils for their social, cultural, economic, educational, ethnic development within the state statutory laws.

Although the Inner Line areas and Sixth Schedule areas have more significant implications in the contemporary political imbroglio. As the Government of India passed the Citizenship Amendment Act (CAA) on 12 December 2019, (which provided that the central government has exempted any person belonging to Hindu, Sikh, Buddhist, Jain, Parsi or Christian community from Afghanistan, Bangladesh or Pakistan, who entered into India on or before the 31 December 2014 by or under clause (c) of sub-section 3 of the Foreigners Act, 1946 or any rule or order made thereunder, shall not be 
treated as an illegal migrant for the purpose of this act (The Gazette of India, 2019). Notwithstanding, the Inner Line Regulation of 1873 , restricts the entries and regulates the stay of outsiders in these designated areas. In this regard, the government has clearly declared that CAA does not apply to the Inner Line Areas and the Sixth Schedule Areas. The Inner Line Permit (ILP) covers the state of Arunachal Pradesh, Mizoram, Nagaland, and recently the regime is also extended to Manipur. However, the Sixth Schedule includes the state of Mizoram, Meghalaya, some districts of Assam, and the Hill areas of Tripura. Hence, these areas are excluded from the purview of CAA. Therefore, ILP and Sixth Schedule areas have become a restricted mechanism for non-applicability of the CAA. At present, excluding the ILP states the other northeastern states are agitating for implementation of ILP to these areas.

\section{Conclusion}

The colonial creation of differentiation and its consequences as an autonomous institution for the exceptional autonomies is significant for relocating conflict in India's Northeast. The autonomy paradigm of the 'tribal' communities under the Sixth Schedule Councils stipulates that, without the consent of the people of scheduled areas no legislative act of the state shall apply to those areas. However, the statutory protection specified by the Constitution of India under the Schedule can be changed by legislation provides; the grounds for conflicting claims. Many areas under the Schedule started agitating for states within India and already some of them have got statehood as like Mizoram and Meghalaya. Further, the constitutional status of the Sixth Schedule itself raises the demands for more autonomous regions within the states by the different communities. In recent times, North East India as a region has been experiencing many social movements based on ethnic politics centring on autonomy.

\section{References}

Baruah, S. (2003). Nationalising Space: Cosmatic Federalism and the politics of Development in Northeast India. Development and Change, 915-
939, https://doi.org/10.1111/j.1467-

7660.2003 .00334

Baruah, S. (2003). Protective Discrimination and Crisis of Citizenship in North East India. Economic and Political Weekly, 1624-1626, https://www.jstor.org/stable/4413479

Baruah, S. (2008). Territoriality, Integrity and Rights in the North-East India. Economic and Political Weekly, 15-19, http://www.jstor.org/stable/40277273.

Baruah, S. L. (2015). A Comprehensive History of Assam. New Delhi: Munshiram Manoharlal Publishers Pvt. Ltd.

Bhattacharjee, J.B. (2018). The Northeast: The Evolution of the idea of a region. Studies in Peoples History, 5 (1), 65-71, DOI: $10.1177 / 2348448918759869$.

Bhattacharyya, R. (2009). Examining the Changing Status and Role of Middle Class Assamese Women: Lessons from the lives of University Students. PhD Thesis, University of Newcastle Upon Tyne NE1 7RU.

Bhaumik, S. (2009). Troubled Periphery, Crisis of India's North East. New Delhi: Sage Publication.

Bob, $\mathrm{H}$ and Vijoy, M. (2005). What was Postcolonialism ?. New Literary History, 36 (3), 375-402, DOI: 10.1353/nlh.2005.0045.

Castro, Juan E. De. (2014). Colonialism and Post Colonialism. 383-390,

https://www.researchgate.net/publication/295 400645.

Constituent Assembly Debates, Official Report (1949). New Delhi: Jainco Art India.

Das, D. (2018, 17 February). Colonial Construction of a Frontier Debating the Inner Line Regulation in Sibsagar- Naga Hills. Economic \& Political Weekly, LIII (7), 52-61, https://www.epw.in/journal/2018/7/specialarticles/colonial-construction-frontier.html.

Fernandes, W. (1999, 18-24 December). Conflict in Northeast: A Historical Perspective. Economic and Political Weekly, 34 (51), 3579- 3582, https://www.jstor.org/stable/4408734. 
Functioning of Autonomous Councils in Sixth Schedule Areas of North Eastern States. 2016, https://www.actionaidindia.org/aadocument/R eport.

Gohain, H. (1997). Ethnic Unrest in the NorthEast. Economic and Political Weekly, 32 (8): 389391, http://www.jstor.org/stable/4405112.

Guha, A. (2006). Planter Raj to Swaraj, Freedom Struggle \& Electoral politics in Assam. New Delhi: Tulika Books.

Guha, R. and Spivak, C. G. (1988). Selected Subaltern Studies. Foreword by Edward W. Said. New York: Oxford University Press.

Hansaria, V. (2005). Justice B.L. Hansaria's Sixth Schedule to the Constitution. New Delhi: Universal Law Publishing.

Hussain, M. (1987). Tribal Movement for Autonomous State in Assam. Economic and Political Weekly, 1329-1332.

Karlsson, B. G. (2014). Indigenous Politics: Community Formation and Indigenous Peoples struggle for Self- Determination in Northeast India. Identities: Global Studies in Culture and Power, 6-45, DOI:

10.1080/1070289X.2001.9962683.

Lahiri, R. M. (1975, Reprint). The Annexation of Assam (1824-1854). Calcutta: Firma KLM.

Mack-Canty, C. (2004). Third-Wave Feminism and the Need to Reweave the Nature/ Culture Duality. NWSA Journal, 16 (3), 154-179.

Mc Duie-Ra, D. (2009). Civil Society, Democratisation and the Search for Human Security: The Politics of Environment, Gender and Identity In Northeast India. New York: Nova Science Publishers, Inc.

Mukerjee, D. (1969). Assam Reorganisation. Asian Survey, 9 (4), 297-311.

Ngaihte, S. T. (2013). The Reality of North East as an Entity. Economic and Political Weekly, XLVIII (50), 13-15.
Pachuau, L. (1997). In Search of A Context for A Contextual Theology: The Socio Political Realities of" Tribal" Christians in Northeast India. National Council of Churches Review 117, 760-772, https://edfo.pw/ufas2drsgo8.pdf.

Piang, L. Lam K. (2013). Ethnic Mobilisation for Decolonisation: Colonial Legacy (the case of the Zo people in Northeast India). Asian Ethnicity, 14 (3), 342-363, https://doi.org/10.1080/14631369.2012.68867 0.

Samaddar, R. (edited, 2005). The Politics of Autonomy, Indian Experiences. New Delhi: Sage Publication.

Sarmah, B. (2016). The Cauldron of Conflict: Politics of Peace, Governence and Development in India's North-East. Social Scientist, 15-36, https://www.jstor.org/stable/24890258.

Singh, B. N. and J. P. Garg (1969, May). Reorganisation of Assam: A Study in the Politics of Regional Alienation in India. The Modern Review, 354-358.

Singh, M. A. (2008). Ethnic Diversity, Autonomy and Territoriality in Northeast India: A Case of Tribal Autonomy in Assam. Strategic Analysis, 32 (6), 1101-1114, DOI: 10.1080/09700160802404588.

Singh, S. (2017, March- April). Micro- history lost in a Global Narrative? Revisiting the Grant of the "Diwani" to the English East India Company. Social Scientist, 45 (3/4), 41-51 The Gazette of India (2019, 12 December). No. 71, New Delhi, http://egazette.nic.in/WriteReadData/2019/21 4646. 